\title{
Robotic Surgery in Gynaecology-A Territory Unvisited
}

\author{
Shalini Malhotra* and Muna Khalfan \\ Department of Obestrics and gynecology, Al Qassimi Hospital for Women and Children, UAE
}

Submission: March 19, 2020; Published: March 23, 2020

*Corresponding author: Shalini Malhotra, Department of Obestrics and gynecology, Al Qassimi Hospital for Women and Children, UAE

\section{Opinion}

The invention of the Robot started a new phase in the era of minimally invasive surgeries-one in which enhanced recovery and early return of the patient to normal life were becoming more important, particularly as healthcare organisations were trying to become more efficient in proving that they could offer surgeries with minimal long term effects on the health of the lady.

The Da Vinci Robot has been considered to be the magical equipment revolutionizing modern laparoscopic surgery. While many have called Robotic Surgery as the safest way to operate, there are no studies to support it. In this method, the surgeon sits on a console away from the patient, operating the fine instruments attached to robotic arms, while observing 10 times magnified coloured 3D images of internal body tissues or the deepest body part the surgery is to be performed. Usually, a laparoscopic vision if like looking at the tissue between instruments and only 2D. The nerves and blood vessels are magnified and chances of accidental injury while performing surgery are negligible. Intra-abdominal adhesions are magnified and seen very closely before they are separated, reducing chances of inadvertent injury to any adjoining structures. The multiple safety measures incorporated in the Da Vinci Robot, are always directed to safeguarding the patients from surgical complications. The minute the surgeon's head is removed from the console, the arms are deactivated. This ensures no movement of instruments inside the patient body when the surgeon is not looking.

In gynaecology, there are no large studies clearly demonstrating the benefit of Robot-assisted surgeries. However, the clear benefits such as early post-op recovery and early discharge encouraged us to promote this method of surgery for complex gynaecological problems among the female population in the Northern emirates. Many women in the region are silent suffers from endometriosis, ignorant about the cause behind many symptoms or infertility they have. Robotic surgery helped incidentally diagnose endometriosis in may cases of robotic ovarian cystectomies, myomectomies and hysterectomies than ever. This helped to correlate symptoms of the women and plan individualised post-op treatment to alleviate symptoms. Women seeking infertility treatment got the additional benefit of this appropriate diagnosis (due to magnification and in depth vision in cul de sac) before being referred to IVF centres.

Grand-multiparity is another unique feature in the population of this region, and though vaginal delivery is usually the preferred mode of delivery, we see many women with previous multiple cesarean sections. In these women adhesions caused by previous surgeries causes many symptoms but they suffer in silence as most gynaecologist would consider it very risky to plan surgery for adhesiolysis. With the help of the Robot, that is, with magnified 3D vision and fine instruments with minimal movement, fine dissection is easily possible with minimal risks of injuries and serious consequences, helping the women get better.

Also, worth mentioning is the comfort of the surgeon using this technology. Even if the case is of Grade 4 endometriosis, his level of stress at dealing with the most complex pathology is much less and he has better vision, ease to access tissue with a greater magnified view-enhancing the safety of his surgical technique making him in a better state of mind to deliver the best care. The satisfaction of the surgeon is enhanced apart from his happiness levels-both of which are also important considering any surgery to be called practical.

Though there are concerns from many about the costeffectiveness of using the technology of Robotic surgery, what is clearly evident is that there are many patient safety issues that are being addressed, increasing the benefit to our women. While the learning curve towards becoming experienced laproscopic surgeon is too long, with huge costs of training programmes and simultors, it's cost can be definitely equated to that of robotic surgery to a larger population, by relatively less experienced yet more empowered gynaecologists who can deal with complex cases with the help of the robot. When a women gets back to her 
home, relieved, with an earlier resumption of a normal routine, society as a whole benefit as is happier. Thus, the authors strongly would like to argue about the benefits of this technique of surgery and how it needs to adopted and made more accessible to many women.



\section{Your next submission with Juniper Publishers will reach you the below assets}

- Quality Editorial service

- Swift Peer Review

- Reprints availability

- E-prints Service

- Manuscript Podcast for convenient understanding

- Global attainment for your research

- Manuscript accessibility in different formats ( Pdf, E-pub, Full Tsext, Audio)

- Unceasing customer service

Track the below URL for one-step submission https://juniperpublishers.com/online-submission.php 